\title{
Potensi Ekosistem Mangrove Sebagai Sumber Bakteri Untuk Produksi Protease, Amilase Dan Selulase
}

\section{Subagiyo*, Muhammad Salauddin Ramadhan Djarod dan Wilis Ari Setyati}

Departemen IImu Kelautan, Fakultas Perikanan dan IImu Kelautan, Universitas Diponegoro JI. Prof. Soedarto, SH. Kampus UNDIP Tembalang, Semarang 50275

Email : subagiyo.kelautan13@gmail.com

\begin{abstract}
The mangrove ecosystem is a productive ecosystem. The production and accumulation of organic matter on the floor of the mangrove ecosystem allows this region to be rich in microbials that are potential to be developed as a source of a wide range of extra cellular enzymes. In this research, bacteria were isolated and used as the source of enzyme. The bacteria were isolated from the existing mangrove sediments on the north coast of Semarang, Central Java. The bacterial potential as a source of protease, amylase and cellulase is done semiquantitatively using well diffusion agar method. The results obtained 18 bacteria isolates which were all capable to produce amylase and cellulase, but only 7 isolates were able to produce proteases. Five isolates had amylase activity above $300 \mathrm{~mm} 2 / \mathrm{ml}$, three isolates with protease activity above $300 \mathrm{~mm} 2 / \mathrm{ml}$ and 2 isolates with cellulase activity of 225.40 and 204.50 $\mathrm{mm} 2 / \mathrm{ml}$. Seven isolates are capable of producing amylase, protease and cellulase. The results showed that mangrove ecosystem is a potential source of microbes to produce enzymes protaese, amylase and cellulase and also possible for various other extracellular enzymes.
\end{abstract}

Keyword : bacteria, mangrove, protease, amylase, cellulose

\begin{abstract}
Abstrak
Ekosistem mangrove merupakan ekosistem produktif. Produksi dan akumulasi bahan organik di lantai ekosistem mangrove memungkinkan daerah ini kaya akan mikrobia yang potensial untuk dikembangkan sebagai sumber berbagai macam enzim ekstra seluler. Pada penelitian ini dilakukan isolasi bakteri sebagai sumber enzim. Bakteri diisolasi dari sedimen mangrove yang ada di pantai Utara Semarang, Jawa Tengah. Pengujian potensi bakteri ini sebagai sumber protease, amilase dan selulase dilakukan secara semikuantitatif menggunakan metode well diffusion agar. Hasil penelitian mendapatkan 18 isolat bakteri yang seluruhnya mampu memproduksi amylase dan selulase, tetapi hanya 7 isolat yang mampu memproduksi protease. Lima isolat memiliki aktivitas amylase diatas $300 \mathrm{~mm} / 2 \mathrm{ml}$, tiga isolat dengan aktivitas protease diatas $300 \mathrm{~mm} / 2 \mathrm{ml}$ dan 2 isolat dengan aktivitas selulase yaitu sebesar 225,40 dan $204,50 \mathrm{~mm} / \mathrm{ml}$. Tujuh isolat yang mampu menghasilkan amylase, protease dan selulase. Hasil penelitian menunjukkan bahwa ekosistem mangrove merupakan sumber potensial mikrobia untuk menghasilkan enzim protaese, amylase dan selulase serta juga dimungkinkan untuk berbagai macam ensim ekstraseluler lainnya.
\end{abstract}

Kata kunci : bakteri, mangrove, protease, amylase dan selulase

\section{PENDAHULUAN}

Lahan lantai hutan mangrove kaya akan bahan organik yang berasal dari produksi seresahnya (Aida, et al., 2014 ; Andrianto, et al., 2015). Di pantai Utara
Jawa Tengah kawasan mangrove biasanya berada atau berdekatan dengan pemukiman dan aktivitas produktif seperti budidaya perikanan, industri pengolahan hasil perikanan, pelabuhan pendaratan ikan. Oleh karena itu kawasan 
mangrove ini mendapat tekanan anthropogenik yang tinggi. Kondisi ini menjadi faktor seleksi alam terhadap keragaman mikrobia yang ada di sedimen mangrove. Seperti diketahui bahwa ekosistem mangrove merupakan sumber berbagai mikrobia yang mampu menghasilkan enzim dan molekul-molekul yang bermanfaat bagi kehidupan manusia, pertanian, perikanan, industri dan bioremediasi (Dourado et al., 2012; Dias et al., 2009). Enzim ekstraseluler diproduksi oleh mikrobia digunakan untuk mengurai material nutrient organik kompleks menjadi sederhana sehingga dapat di transport masuk ke dalam sel sebagai sumber nutrisinya. Kompleksitas ekosistem mangrove dengan tekanan anthropegenik ini mengharuskan mikrobia menghasilkan enzim ekstraseluler yang mampu bekerja dalam kondisi yang kompleks ini. Enzim adalah protein fungsional yang sensitive terhadap faktor lingkungan, sehingga enzim yang dihasilkan oleh mikrobia dalam kompleksitas ekosistem merupakan enzim yang memiliki toleransi yang tinggi terhadap faktor lingkungan. Pada penelitian ini dilakukan kajian mengenai potensi bakteri mangrove sebagai sumber selulase. Selulase merupakan salah satu industrial enzyme utama dengan pemanfaatan yang beragam seperti pada industri pengolahan kapas, daur ulang kertas, formulasi pada detergen, ekstraksi jus, aditif pada pakan ternak, serta aplikasinya dalam bioteknologi pertanian dan juga bioenergi (Phitsuwan, et al., 2013). Protease dimanfaatkan secara beragam pada berbagai industri seperti detergen, kulit, makanan, farmasi, tekstil, dan proses bioremediasi (Hamza, 2017). Amilase dimanfaatkan dalam dunia industri meliputi diantaranya konversi pati, industri detergen, produksi alkohol, industri makanan, tekstil dan kertas (de Souza \& E Magalhães, 2010).

Ekosistem mangrove merupakan sumber potensial bakteri penghasil proteinase, amylase dan selulase. Hal ini terkait dengan protein, karbohidrat dan selulosa yang melimpah di sedimen mangrove. Hasil penelitian Aida et al., menunjukkan bahwa komponen utama seresah mangrove adalah daun (Aida, et al., 2014 dan Andrianto, 2015). Daun mangrove Avicenia marina mengandung selulosa sebanyak $19 \%$, total gula 4,6\% (Mouafi et al., 2013). Sehingga ekosistem mangrove merupakan sumber penting bacterial proteinase, amylase dan selulase. Pentingnya enzim mikrobia dan bioteknologinya telah direview untuk selulase (Behera et al., 2016), amylase (de Souza \& e Magalhães, 2010 dan Dar et al., 2014), dan protease (Mienda et al., 2014 ; Sawant \& Nagendran, 2014 dan Hamza, 2017).

\section{MATERI DAN METODE}

\section{Pengambilan Sampel Sedimen}

Sampel sedimen ekosistem mangrove diambil di Daerah Tugurejo, Kecamatan Tugu, Kota Semarang, Jawa Tengah. Pengambilan sampel dilakukan menggunakan sekop dengan kedalaman $\pm 10 \mathrm{~cm}$. Sampel yang didapatkan kemudian dimasukkan kedalam plastik zipplock dan dimasukkan ke dalam coolbox.

Isolasi bakteri dilakukan dengan teknik pour plate menggunakan media deMann Rogosa Sharpe (MRS) yang diperkaya dengan $\mathrm{CaCO}_{3} 1 \%$. Sepuluh gram sampel sedimen dihomogenasikan di dalam $90 \mathrm{~mL}$ larutan garam fisiologis kemudian dibuat seri pengenceran hingga $10^{3}$. Tiap seri pengenceran dilakukan penanaman di dalam media $\mathrm{MRS}+\mathrm{CaCO}_{3}$ dengan metode pour plate dan di inkubasi selama 24 jam pada suhu kamar. Kolonikoloni bakteri yang tumbuh di pilih yang membentuk zona bening (indikator sebagai bakteri asam). Tiap-tiap koloni dimurnikan dengan teknik streak plate.

Isolat-isolat bakteri diuji kemampuan menghasilkan enzim proteolitik, amilolitik dan selulolitik dengan metode well diffusion agar. Kultur isolat uji umur 24 jam disentrifugasi pada kecepatan 5.000 rpm. Seratus $\mu$ supernatant dipipetkan ke dalam sumuran yang dibuat dalam medium uji (medium Zobell yang diperkaya dengan skim milk $1 \%$ digunakan untuk uji akitivitas protease, medium Zobell yang diperkaya dengan soluble starch $1 \%$ digunakan untuk 
uji akitivitas amilale, medium Zobell yang diperkaya dengan CMC $1 \%$ digunakan untuk uji akitivitas selulase). Inkubasi dilakukan selama 24 jam pada suhu kamar. Aktivitas proteolitik ditunjukkan dengan munculnya zona bening disekitar sumuran. Aktivitas amylase dilakukan dengan menuangkan larutan iodin $1 \%$ ke permukaan medium agar. Terbentuknya zona bening menunjukkan adanya aktivitas amylase. Aktivitas selulase di diamati dengan cara meneteskan larutan iodin $1 \%$ ke permukaan medium agar dan kelebihannya dibuang. Terbentuknya zona bening menunjukkan adanya aktivitas selulase. Aktivitas enzim dihitung sebagai selisih luas zona hidrolisis dengan luas paper disk per ml supernatant kultur.

\section{HASIL DAN PEMBAHASAN}

Hasil isolasi bakteri dari sedimen mangrove diperoleh 18 isolat yang berbeda berdasarkan karakter morfologi koloni yang meliputi warna, bentuk, elevasi, permukaan dan margin (Tabel 1).

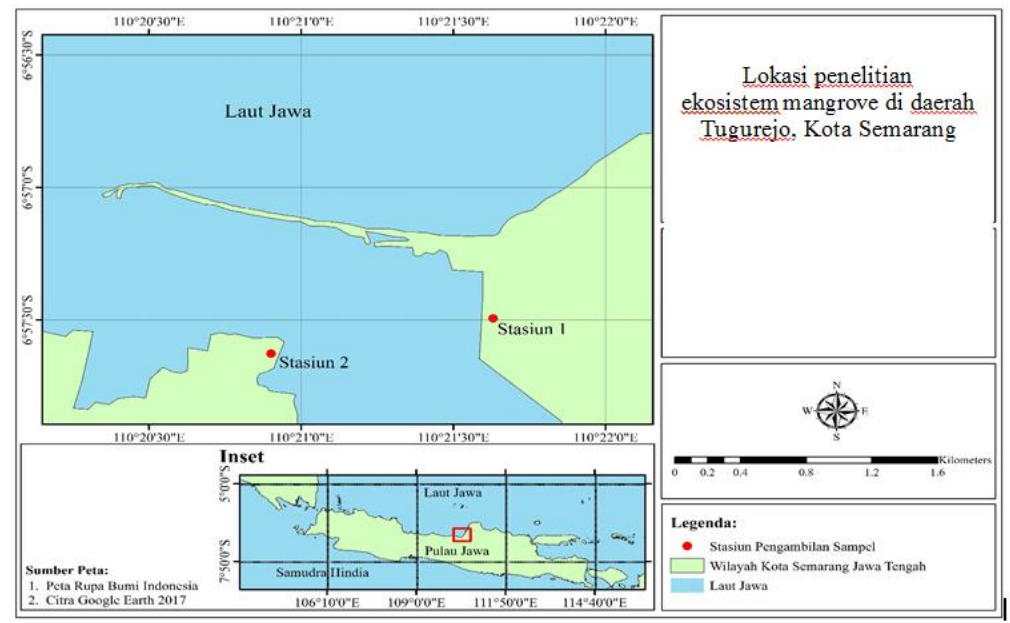

Gambar 1. Peta lokasi pengambilan sampel

Tabel 1. Karakterisasi Koloni Isolat Bakteri Penghasil Asam dari Sedimen Mangrove di Daerah Semarang, Jawa Tengah

\begin{tabular}{ccccccc}
\hline No & Kode bakteri & Warna & Bentuk & Elevasi & Permukaan & Margin \\
\hline 1 & SMM 1.1 & PT & Circular & Flat & HM & Entire \\
2 & SMM 1.2 & PS & Irregular & Raised & HM & Undulate \\
3 & SMM 1.3 & PS & Irregular & Flat & HM & Undulate \\
4 & SMM 1.4 & PB & Circular & Flat & HM & Entire \\
5 & SMM 1.5 & PS & Circular & Flat & HM & Entire \\
6 & SMM 2.4 & PT & Irregular & Flat & HM & Undulate \\
7 & SMM 3.5 & PS & Circular & Flat & HM & Lobulate \\
8 & SMT 1.2 & PS & Irregular & Flat & HM & Entire \\
9 & SMT 1.3 & PS & Circular & Flat & HM & Entire \\
10 & SMT 1.5 & PS & Irregular & Flat & HM & Lobulate \\
11 & SMT 1.6 & PS & Filamentous & Flat & HM & Lobulate \\
12 & SMT 1.7 & PT & Irregular & Flat & HM & Lobulate \\
13 & SMT 2.5 & PT & Circular & Flat & HM & Entire \\
14 & SMT 2.6 & PT & Irregular & Raised & HM & Undulate \\
15 & SMT 2.7 & PT & Irregular & Raised & HM & Lobulate \\
16 & SMT 3.5 & PS & Irregular & Flat & HM & Undulate \\
17 & SMT 3.6 & PS & Circular & Raised & HM & Entire \\
18 & SMT 4.5 & PS & Irregular & Raised & HM & Lobulate \\
\hline
\end{tabular}

Keterangan:

SMM merupakan isolat bakteri penghasil asam yang didapatkan dari sedimen mangrove Maron, sedangkan SMT merupakan isolat bakteri penghasil asam yang didapatkan dari sedimen mangrove Tapak Daerah Tugurejo, Kota Semarang, Jawa Tengah. PT = Putih Tulang, PS = Putih Susu, PB = Putih Bening, HM = Halus Mengkilap 

Hasil isolasi bakteri dari sedimen mangrove diperoleh 18 isolat yang memiliki kenampakan koloni yang berbeda. Hasil karakterisasi koloni isolat disajikan pada Tabel 1.

\section{Hasil uji produksi amilase, protease dan selulase terhadap 18 isolat menunjukkan seluruhnya mampu memproduksi amylase dan selulase, tetapi hanya 7 isolat yang mampu memproduksi protease. Aktivitas amilase ditunjukkan dari luas zona hidrolisis yang terbentuk dari $1 \mathrm{ml}$ supernatant kultur isolat uji. Pada pengujian ini aktivitas amylase dari 18 isolat berkisar antara 12.690 sampai $47.800 \mathrm{~cm}^{2} / \mathrm{ml}$.}

Berdasarkan hasil perhitungan besarnya aktivitas hidrolitik enzim amylase diperoleh 5 isolat dengan aktivitas yang diatas $300 \mathrm{~mm}^{2} / \mathrm{ml}$ yaitu SMT 1.6, SMT 4.5 , SMT 1.5, SMT 2.5, dan SMM 1.3, berturutturut dengan aktivitas sebesar 478,20; 470,$90 ; 331,30 ; 323,50$ dan $302,40 \mathrm{~mm}^{2} / \mathrm{ml}$.

Aktivitas terendah ditunjukkan oleh isolat SMM 1.1 yaitu sebesar $126,9 \mathrm{~mm}^{2} / \mathrm{ml}$. Tiga isolat dengan aktivitas protease diatas 300 mm²/ml SMT 3.5, SMT 4.5 dan SMT 3.6 dengan aktivitas berturut-turut sebesar 457,$10 ; 406,30$ dan $333,40 \mathrm{~mm}^{2} / \mathrm{ml}$. Isolat yang menghasilkan protease dengan aktivitas terendah adalah SMM 1.3 yaitu $175,80 \mathrm{~mm} 2 / \mathrm{ml}$. Tidak ada satupun isolat yang menghasilkan selulase dengan aktivitas diatas $300 \mathrm{~mm} 2 / \mathrm{ml}$. Aktivitas selulase tertinggi dihasilkan oleh isolat SMT 2.5 dan SMM 2.4 yaitu sebesar 225,40 dan $204,50 \mathrm{~mm}^{2} / \mathrm{ml}$. Pada penelitian ini diperoleh 7 isolat yang mampu menghasilkan ke tiga jenis enzim yaitu SMM 1.2, SMM 1.3, SMT 1.3, SMT 2.7, SMT 3.5, SMT 3.6 dan SMT 4.5.

Isolat bakteri mangrove yang memiliki kemampuan menghasil beragam enzim juga dilaporkan oleh para peneliti. Tabao et al (2010) melaporkan 10 isolat bakteri penghasil selulase yang diisolasi dari berbagai lokasi mangrove di Filipina. Thompson et al (2013) juga melaporkan isolat bakteri selulolitik dari mangrove di Brazil, Castro, et al (2014) mendapatkan bakteri yang diisolasi dari ekosistem mangrove Brazil mampu menghasilkan protease dan amylase. Foophow \& Tangjitjaroenkun (2014) mengidentifikasi jenis-jenis Bacillus yang mampu menghasilkan enzim proteolitik diisolasi dari sedimen hutan mangrove Chanthabur. Kanimozhi et al. (2014) mengidentifikasi jenis-jenis Bacillus penghasil amilase dari Muthupettai mangroves, India. Sonawale et al. (2016) memperoleh 7 isolat bakteri

Tabel 2. Karakterisasi Koloni Isolat Bakteri Penghasil Asam dari Sedimen Mangrove di Daerah Semarang, Jawa Tengah

\begin{tabular}{cccc}
\hline \multirow{2}{*}{ Kode Isolat } & \multicolumn{3}{c}{ Aktivitas Enzim Ekstraseluler $\left(\mathrm{cm}^{2} / \mathrm{ml}\right)$} \\
\cline { 2 - 4 } & Amilase & Protease & Selulase \\
\hline SMM 1.1 & $126,9 \pm 01,8$ & 0 & $82,3 \pm 12,9$ \\
SMM 1.2 & $242,6 \pm 36,3$ & $183,7 \pm 6,3$ & $112,5 \pm 15,2$ \\
SMM 1.3 & $302,4 \pm 17,1$ & $175,8 \pm 8,4$ & $94,2 \pm 18,3$ \\
SMM 1.4 & $209,1 \pm 7,9$ & 0 & $103,5 \pm 4,5$ \\
SMM 1.5 & $214,8 \pm 11,3$ & 0 & $49,1 \pm 16,9$ \\
SMM 2.4 & $225,6 \pm 16,2$ & 0 & $204,5 \pm 29,4$ \\
SMM 3.5 & $261,5 \pm 13,3$ & 0 & $147,1 \pm 33$ \\
SMT 1.2 & $193,5 \pm 24,2$ & 0 & $155,4 \pm 30,8$ \\
SMT 1.3 & $259,7 \pm 41,9$ & $243,4 \pm 3,2$ & $92,3 \pm 8,5$ \\
SMT 1.5 & $331,3 \pm 40,6$ & 0 & $105,6 \pm 19,5$ \\
SMT 1.6 & $478,2 \pm 65,2$ & 0 & $118,9 \pm 7,4$ \\
SMT 1.7 & $284,2 \pm 46,3$ & 0 & $66,4 \pm 17,2$ \\
SMT 2.5 & $323,5 \pm 10,18$ & 0 & $225,4 \pm 3,7$ \\
SMT 2.6 & $285,2 \pm 2,97$ & 0 & $103,1 \pm 3,3$ \\
SMT 2.7 & $210,0 \pm 0,51$ & $287,1 \pm 25,5$ & $134,9 \pm 4,3$ \\
SMT 3.5 & $291,9 \pm 3,62$ & $457,1 \pm 29,5$ & $121,4 \pm 4,7$ \\
SMT 3.6 & $183,6 \pm 14,67$ & $333,4 \pm 63,6$ & $110,6 \pm 1,2$ \\
SMT 4.5 & $470,9 \pm 2,34$ & $406,3 \pm 3,8$ & $935 \pm 6,1$ \\
\hline
\end{tabular}


penghasil selulase dan 3 isolat bakteri penghasil amilase dari mangrove di Ratnagairi, India. Chantarasiri (2016) mengidentifikasi Bacillus cereus yang memiliki aktivitas selulase dari mangrove di Thailand. Bibi et al (2017) mengidentifikasi 14 bakteri selulotik, 4 proteolitik dan 9 isolat amilolitik dari ekosistem mangrove Thuwal, Jeddah, Saudi Arabia.

Berdasarkan besarnya aktivitas hidrolisis yang dihasilkan isolat SMT 1.6, SMT 4.5, SMT 1.5, SMT 2.5, dan SMM 1.3 potensial untuk dikembangkan menjadi sumber amylase untuk berbagai kebutuhan industri. Amilase adalah enzim hidrolisis yang telah lama dikenal dan diaplikasikan di bidang industri. Enzim ini secara random memecah ikatan glikosida pada molekul pati dan menghidrolisisnya dan menghasilkan dekstrin dan oligosakarida (Sundarram, et al., 2014). Isolat SMM 2.4 dan SMT 2.5 potensial untuk dikembangkan sebagai sumber selulase. Selulase adalah keluarga dari sekurang-kurangnya 3 kelompok enzim endo-(1,4)- $\beta$-D-glucanase (EC 3.2.1.4), exo-(1,4)- $\beta$-D-glucanase (EC 3.2.1.91), dan $\beta$-glucosidases (EC 3.2.1.21). Eksoglukanase bekerja di kedua ujung rantai selulosa dan menghasilkan $\beta$ cellobiose, endoglukanase sevara random memecah ikatan O-glycosidic dan menghasilkan rantaian glukan dengan panjang yang bervariasi, $\beta$-glycosidases secara spesifik bekerja pada disakarida $\beta$ cellobiose dan menghasilkan glukosa (Kuhad et al., 2011).

Berdasarkan hasil penelitian ini maka disimpulkan bahwa ekosistem mangrove merupakan sumber bakteri yang memiliki kemampuan menghasilkan berbagai macam enzim ekstraseluler khususnya protease, amylase dan selulase yang memiliki nilai penting di bidang industri. Pada penelitian ini isolasi bakteri dilakukan di sedimen lantai ekosistem mangrove, sehingga potensi bagian lain ekosistem ini masih memberikan peluang diperolehnya keragaman bakteri dengan berbagai aktivitas enzim ekstraselulernya.

\section{DAFTAR PUSTAKA}

Aida, G.R., Wardiatno, Y., Fahrudin, A., Mohammad \& Kamal, M., 2014.
Produksi Serasah Mangrove Di Pesisir Tangerang, Banten. J. Ilmu Pertanian Indonesia. 19(2):91-97

Andrianto, F., Bintoro, A. \& Yuwono, S.B., 2015. Produksi Dan Laju Dekomposisi Serasah Mangrove (Rhizophora Sp.) Di Desa Durian Dan Desa Batu Menyan Kecamatan Padang Cermin Kabupaten Pesawaran. Jurnal Sylva Lestari. 3(1):9-20.

Behera, B.C., Sethi, B.K., Mishra, R.R., Dutta, S.K. \& Thatoi, H.N., 2017. Microbial cellulases - Diversity \& biotechnology with reference to mangrove environment: A review. J. Genetic Eng. Biotechnol. 15:197-210

Bibi, F., Ullah, I., Alvi, S.A., Bakhsh, S.A., Yasir, M., Al-Ghamdi, A.A.K. \& Azhar, E.I., 2017. Isolation, diversity, and biotechnological potential of rhizoand endophytic bacteria associated with mangrove plants from Saudi Arabia. Genetics and Molecular Res. 16:(2). DOI : 10.4238/gmr16029657

Castro, R. A., Quecine, M. C., Lacava, P. T., Batista, B. D., Luvizotto, D. M., Marcon, J. \& Azevedo, J. L. 2014. Isolation and enzyme bioprospection of endophytic bacteria associated with plants of Brazilian mangrove ecosystem. SpringerPlus. 3:382. DOI : 10.1186/21931801-3-382

Chantarasiri, A., 2015, Aquatic Bacillus cereus JD0404 isolated from the muddy sediments of mangrove swamps in Thailand and characterization of its cellulolytic activity. Egyp. J. Aquatic Res. 41:257264

Dar, G.H., Kamili, A.N., Nazir, R., Bandh, S.A. \& Malik, T.A., 2014. Biotechnological Production Of A-Amylases For Industrial Purposes : Do Fungi Have Potential To Produce A- Amylases, International J. Biotechnol. Molecul. Biol. Res.5(4):35-40

De Souza, P.M. \& Magalhães, P.De.O.E 2010. Application Of Microbial $\beta$ Amylase In Industry: A Review. Brazilian J. Microbiol. 41: 850-861

Dias, A.C.F, Andreote, F.D., Dini-Andreote, F., Lacava, P.T., Sá, A.L.B., Melo, I.S., Azevedo, J.L. \& Araújo, W.L. 2009. Diversity And Biotechnological Potential Of Culturable Bacteria From 
Brazilian Mangrove Sediment. World J. Microb. Biot. 3(7):1305-1311.

Dourado, M.N., Ferreira, A., Araújo, W.L., Azevedo, J.L., \& Lacava, P.T., 2012. The Diversity Of Endophytic Methylotrophic Bacteria In An Oil-Contaminated And An Oil-Free Mangrove Ecosystem And Their Tolerance To Heavy Metals. Biotechnol. Res. Int. DOI : 10.1155/2012 1759865

Hamza, T.A., 2017. Bacterial Protease Enzyme: Safe And Good Alternative For Industrial And Commercial Use. Int. J. Chem. Biomol. Sci. 3(1):1-10

Kanimozhi, M., Johny, M., Gayathri, N. \& Subashkumar, R., 2014. Optimization and Production of a -Amylase from Halophilic Bacillus Species Isolated from Mangrove Soil Sources. J. App. Environ. Microbiol. 2(3):70-73

Mienda, B.S., Yahya, A., Galadima, I.A. \& Shamsir, M.S. 2014. An Overview Of Microbial Proteases For Industrial Applications. Res. J. Pharma. Biol. Chem. Sci. 5(1):388- 396

Mouafi, F.E., Aziz, S.M.A. \& Bashir, A.A. 2013. Nutritive Value Of Ensiled Mangrove Leaves By Lactobacillus Plantarum I. Fermentation Characteristics And Chemical Composition. World App. Sci. J. 28(4):499-508
Phitsuwan, P., Laohakunjit, N., Kerdchoechuen, O., Kyu, K.L. \& Ratanakhanokchai, K. 2013. Present And Potential Applications of Cellulases In Agriculture. Biotechnol. Bioenergy Folia Microbiol. 58(2):163176

Sawant, R. \& Nagendran, S. 2014. Protease: An Enzyme With Multiple Industrial Applications. World J. Pharm. Pharmaceut. Sci. 3(6):568-579.

Sonawale, S B., 2016. Studies on Enzymes Extracted From Microbes Isolated From Mangrove Sediments. Res J. Chem. Environ. Sci. 4(2): 27-31

Tabao, N.S.C. \& R.G. Monsalud. 2010. Screening And Optimization Of Cellulase Production of Bacillus Strains Isolated From Philippine Mangroves, Philippine J. Systematic Biol. Vol. IV.

Thompson, C.E., Beys-da-Silva, W.O., Santi, L., Berger, M., Vainstein, M.H., Guima rães, J.A. \& Vasconcelos, A.T.R., 2013. A potential source for cellulolytic enzyme discovery and environmental aspects revealed through metagenomics of Brazilian mangroves, AMB Express. 3:65. 